\title{
SINTESIS DAN KARAKTERISASI MATERIAL HIBRIDA Mg/Al- LDH TERIMOBILISASI ASAM PARA HIDROKSIBENZOAT
}

\author{
Lutfi Aditya Hasnowo ${ }^{*}$, Sri Juari Santosa², Bambang Rusdiarso²
}

1) Sekolah Tinggi Teknologi Nuklir - BATAN, Yogyakarta, lutfi.aditya@batan.go.id

2) Universitas Gadjah Mada, Yogyakarta

\begin{abstract}
ABSTRAK
SINTESIS DAN KARAKTERISASI MATERIAL HIBRIDA MG/AL-LDH TERIMOBILISASI ASAM PARA HIDROKSIBENZOAT. Telah dilakukan sintesis dan karakterisasi material hibrida Mg/Al-LDH terimobilisasi APHB. Mg/Al-LDH terimobilisasi APHB disintesis melalui sintesis tidak langsung dimana APHB diadsorpsikan pada material Mg/Al-LDH. Optimasi sintesis material hibrida dilakukan dengan mengamati pengaruh konsentrasi molar APHB dan pH sintesis. Padatan hibrida hasil sintesis dikarakterisasi dengan spektrometer XRD dan FTIR. Hasil penelitian menunjukkan bahwa sintesis $\mathrm{Mg}$ /Al-LDH terimobilisasi APHB optimum dilakukan pada $\mathrm{pH}$ 7. Berdasarkan model non linear isoterm Langmuir, diperoleh kapasitas Mg/Al-LDH untuk imobilisasi APHB adalah 62,16 mg g $\mathrm{g}^{-1}$, yang artinya per gram Mg/Al-LDH mengandung $62,16 \mathrm{mg} \mathrm{g}^{-1} \mathrm{APHB}$, dengan nilai konstanta Langmuir $\left(K_{a}\right)$ sebesar $0,31 \mathrm{~L} \mathrm{mg}^{-1}$. Hasil karakterisasi menggunakan XRD menunjukkan bahwa nilai parameter kisi $a$, kisi $c$ dan basal spacing $d_{003}$ hibrida Mg/Al-LDH terimobilisasi APHB masing-masing 3,06; 23,70 dan 7,09 $\AA$, dimana APHB berada di permukaan luar lapisan hibrida. Hal ini juga didukung oleh hasil identifikasi melalui spektroskopi FTIR bahwa terdapat terdapat gugus-gugus fungsi spesifik asam para hidroksibenzoat di material hibrida tersebut.
\end{abstract}

Kata kunci: Mg/Al-LDH, asam para hidroksibenzoat, kopresipitasi.

\section{ABSTRACT}

SYNTHESIS AND CHARACTERIZATION OF PHBA IMMOBILIZED Mg/Al-LDH HYBRID. It has been conducted the synthesis of p-hydroxybenzoic acid (PHBA) intercalated Mg/Al-LDH and PHBA immobilized Mg/Al-LDH hybrid. PHBA immobilized Mg/Al-LDH hybrid was prepared by indirect synthesis, where PHBA anions were attached on the surface of Mg/Al-LDH material. To obtain optimum synthesis condition of the hybrid, effect of medium acidity and molar concentration of PHBA have been examined. The synthesized hybrids were characterized by X-ray Diffraction and FT-IR Spectroscopy. The synthesis of the PHBA immobilized Mg/Al-LDH hibrid was optimum at $\mathrm{pH}$ 7. Langmuir isotherm model for the APHB immobilization by the materials $\mathrm{Mg} / \mathrm{Al}-\mathrm{LDH}$ hybrid has capacity $62.16 \mathrm{mg} \mathrm{g}^{-1}$ with Langmuir $\left(K_{a}\right)$ value 0,31 $L \mathrm{mg}^{-1}$. Results showed that the PHBA immobilized Mg/Al-LDH hibrid has lattice parameter of $a=3.06 \AA$, lattice parameter of $c=23.70 \AA$ and basal spacing $d_{003}=7.09 \AA$, where $P H B A$ was attached on the outer surface of the hybrid. Results of FTIR spectroscopy also showed that there were functional groups of APHB on those hybrid material.

Key words: Mg/Al-LDH, p-hydroxybenzoic acid, coprecipitation.

\section{PENDAHULUAN}

Kajian kimia material dalam bidang penelitian kimia mengalami perkembangan yang ekstensif. Kombinasi antara beberapa jenis material yang berbeda dapat menghasilkan material jenis baru, seperti memodifikasi suatu material anorganik menggunakan senyawa organik dengan gugus fungsi tertentu [1]. Material yang terbentuk disebut material hibrida. Penggabungan senyawa anorganik dan senyawa organik menjadi material hibrida didasarkan pada tujuan akhir fungsi material tersebut. Salah satu material hibrida yaitu material hibrida berbasis layered double 
hydroxides $(\mathrm{LDH})$ dan senyawa organik dengan kemampuan tertentu.

LDH yang juga disebut dengan hidrotalsit merupakan hidroksida ganda terlapis terdiri atas lapisan brucite-like berdimensi 2 (2D) bermuatan positif. Muatan positif lapisan brucite-like dinetralkan oleh anion antar lapis yang mudah dipertukarkan. Adanya jaringan ikatan hidrogen antar lapisan LDH mengakibatkan terjadinya penumpukan lapisanlapisan, sehingga menghasilkan LDH dalam bentuk ruah (bulky) yang mempunyai karakter tiga dimensi (3D). LDH mempunyai karakter unik, di samping mudah disintesis, mempunyai anion antar lapis yang mudah dipertukarkan, dan mempunyai luas permukaan yang besar. LDH juga mempunyai muatan total positif sehingga sering dimanfaatkan sebagai adsorben [2].

Pemanfaatan LDH sebagai adsoerben banyak digunakan dalam proses penghilangan limbah logam berat. Dalam lingkup kenukliran, adsorben berbasis LDH dimanfaatkan dalam proses adsorpsi limbah radioaktif. LDH yang dimodifikasi dengan polisulfida telah mampu mengadsorpsi uranium sebanyak lebih dari $95 \%$ dari uranium semula [3]. Selain itu, Feng (2016) juga melaporkan bahwa LDH yang dimodifikasi dengan tiosianat mampu memungut ulang uranium sebanyak $338,43 \mathrm{mg}$ tiap gram adsorben [4]. Dalam proses pemanfaatan LDH sebagai adsorben, modifikasi LDH bertujuan meningkatan efektivitas adsorben dalam proses pengambilan suatu spesies target atau menambah kemampuan tertentu dari LDH itu sendiri. Ada beberapa jenis modifikasi LDH, namun yang paling sering dikaji yaitu imobilisasi senyawa organik ke permukaan lapisan LDH. Penelitian mengenai imobilisasi LDH dengan senyawa organik tertentu telah banyak dilakukan. Fitriani (2013) melakukan imobilisasi asam galat pada $\mathrm{Mg} / \mathrm{Al}-\mathrm{LDH}$ untuk pengambilan $\left[\mathrm{AuCl}_{4}\right]^{-}$. Hasil penelitian Fitriani (2013) adalah $\mathrm{Mg} / \mathrm{Al}$ yang terimobilisasi oleh asam galat dapat mengadsorpsi sekaligus mereduksi $\left[\mathrm{AuCl}_{4}\right]^{-}$menjadi $\mathrm{Au}(0)$ [5].

Berbagai metode telah diterapkan dalam proses sintesis LDH. Salah satu metode yang mempunyai tingkat efisiensi dan efektifitas dalam mensintesis LDH adalah metode kopresipitasi.

Asam para hidroksibenzoat (APHB) merupakan senyawa turunan asam benzoat yang mempunyai gugus hidroksil (-OH) terikat pada cincin aromatis. Keberadaan gugus hidroksil mengakibatkan APHB mempunyai sifat mereduksi. APHB mempunyai nilai potensial reduksi -0,5037 V [6]. Penelitian APHB sebagai reduktor pernah dilakukan oleh Maghfiroh (2015), dimana APHB digunakan sebagai agen pereduksi $\mathrm{AgNO}_{3}$ menjadi $\mathrm{Ag}(0)$. Penelitian Maghfiroh (2015) menunjukkan bahwa APHB merupakan reduktor terbaik dalam proses reduksi $\mathrm{Ag}(\mathrm{I})$ menjadi $\mathrm{Ag}(0)$ dibandingkan dengan asam orto hidroksibenzoat dan asam galat. Nilai potensial reduksi $\operatorname{Ag}(\mathrm{I})$ sebesar $+0,800 \mathrm{~V}$ sedangkan $\left[\mathrm{AuCl}_{4}\right]^{-}$sebesar $+1,002 \mathrm{~V}$ [7]. Nilai potensial $\left[\mathrm{AuCl}_{4}\right]^{-}$lebih positif dibandingkan $\mathrm{AgNO}_{3}$ sehingga diharapkan APHB juga dapat digunakan sebagai reduktor $\left[\mathrm{AuCl}_{4}\right]^{-}$menjadi $\mathrm{Au}(0)$.

Sintesis penggabungan dua jenis senyawa, yaitu LDH dan APHB diharapkan terbentuk material hibrida baru yang mempunyai kemampuan ganda dalam proses removal $\left[\mathrm{AuCl}_{4}\right]^{-}$. Oleh kerena itu, pada penelitian ini dilakukan sintesis material hibrida $\mathrm{Mg} / \mathrm{Al}-\mathrm{LDH}$ terimobilisasi APHB melalui metode indirect synthesis dan karakterisasinya menggunakan X-Ray Diffraction dan Fourier Transform Infrared Spectrometer.

\section{METODE}

\section{Preparasi Mg/Al-LDH}

Sejumlah $12,821 \quad \mathrm{~g} \quad(0,05 \mathrm{~mol})$ $\mathrm{Mg}\left(\mathrm{NO}_{3}\right)_{2} \cdot 6 \mathrm{H}_{2} \mathrm{O}$ dicampur dengan 9,378 $\mathrm{g}$ (0.025 mol) $\mathrm{Al}\left(\mathrm{NO}_{3}\right)_{3} \cdot 9 \mathrm{H}_{2} \mathrm{O}$, dan keduanya selanjutnya dilarutkan dalam $100 \mathrm{~mL}$ akuades bebas $\mathrm{CO}_{2}$. $\mathrm{Ke}$ dalam larutan tersebut ditambahkan larutan $\mathrm{NaOH}$ 0,5 M tetes demi tetes sampai larutan campuran mencapai $\mathrm{pH} 10$ dan dilanjutkan dengan diaduk \pm 30 menit sambil dialiri gas $\mathrm{N}_{2}$. Larutan campuran kemudian dipanaskan dalam oven pada suhu $120{ }^{\circ} \mathrm{C}$ selama 5 jam, selanjutnya didinginkan hingga proses pengendapannya sempurna. Endapan dipisahkan dari larutannnya dengan cara centrifuge. Endapan yang diperoleh dicuci dengan akuades hingga $\mathrm{pH}$ netral dan disaring menggunakan kertas whatman no. kemudian dikeringkan dalam oven pada suhu $70{ }^{\circ} \mathrm{C}$ selama 48 jam. Karakterisasi padatan hasil sintesis dilakukan dengan spektrometer FTIR untuk mengetahui vibrasi gugus fungsi yang ada pada material hibrida dan difraktometer XRD untuk 
menentukan tingkat kristalinitas dengan kisaran sudut $2 \theta$ yang digunakan antara $2-80^{\circ}$.

\section{Imobilisasi asam para hidroksibenzoat pada Mg/Al-LDH}

\section{Pengaruh pH}

Sebanyak 0,010 g Mg/Al-LDH diinteraksikan dengan $10 \mathrm{~mL}$ larutan APHB dengan konsentrasi $100 \mathrm{mg} \mathrm{L}^{-1}$. Harga $\mathrm{pH}$ larutan divariasi dari $\mathrm{pH} 3 ; 5 ; 7 ; 9$; dan 11 dengan cara menambahkan larutan $\mathrm{HCl}$ atau $\mathrm{NaOH}$. Selanjutnya larutan digojog selama 90 menit, setelah itu disaring dengan kertas Whatman no. 42. Konsentrasi APHB dalam larutan diukur dengan spektrofotometer UV-Visibel pada panjang gelombang serapan maksimum.

\section{Penentuan model isoterm adsorpsi.}

Larutan APHB sebanyak $10 \mathrm{~mL}$ dengan $\mathrm{pH}$ optimum diinteraksikan pada $0,01 \mathrm{~g} \mathrm{Mg} / \mathrm{Al}-$ LDH pada variasi konsentrasi APHB $0 ; 10 ; 25$; 50; 100; 200; 300 dan $400 \mathrm{mg} \mathrm{L}^{-1}$. Selanjutnya digojog selama 90 menit, dan dilanjutkan penyaringan dengan kertas saring Whatman no. 42. Konsentrasi APHB dalam larutan diukur dengan spektrofotometri UV-Visibel pada panjang gelombang serapan maksimum.

\section{Karakterisasi Mg/Al-LDH terimobilisasi APHB.}

$\mathrm{Mg} / \mathrm{Al}-\mathrm{LDH} \quad$ sebanyak $\quad 0,010 \quad \mathrm{~g}$ digunakan untuk mengadsorpsi $100 \mathrm{~mL}$ larutan APHB pada kondisi $\mathrm{pH}$ dan konsentrasi optimum dengan waktu kontak 90 menit. Endapan dipisahkan dari larutan dengan penyaringan menggunakan kertas saring whatman no. 42. Endapan selanjutnya dikeringkan dan dikarakterisasi menggunkan spektrometer FTIR untuk mengetahui vibrasi gugus fungsi yang ada pada adsorben hibrida dan difraktometer XRD untuk menentukan tingkat kristalinitas dengan kisaran sudut $2 \theta$ yang digunakan antara $2-80^{\circ}$.

\section{HASIL DAN PEMBAHASAN}

\section{Sintesis dan karakterisasi Mg/Al-LDH}

Metode kopresipitasi digunakan dalam sintesis material $\mathrm{Mg} / \mathrm{Al}-\mathrm{LDH}$, di man dalam penelitian ini digunakan perbandingan rasio mol $\mathrm{Mg} / \mathrm{Al}$ sebesar 2:1 karena Mg/Al-LDH dengan rasio $\mathrm{Mg} / \mathrm{Al}=2$ mempunyai rapat muatan paling besar pada antar lapisnya dibanding $\mathrm{Mg} / \mathrm{Al}-\mathrm{LDH}$ dengan rasio molar $\mathrm{Mg} / \mathrm{Al}$ sebesar 2,5; 3; atau 3,5 [8].

Spektra FTIR hasil karakterisasi dari $\mathrm{Mg} / \mathrm{Al}-\mathrm{LDH}$ disajikan oleh Gambar 1. Analisis FTIR bertujuan untuk menentukan secara kualitatif gugus-gugus fungsional $\mathrm{Mg} / \mathrm{Al}-\mathrm{LDH}$ hasil sintesis.

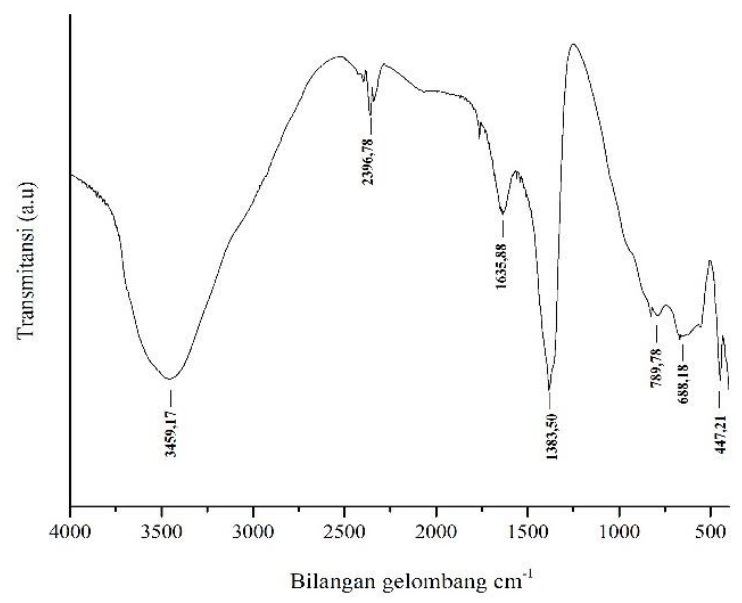

Gambar 1. Spektra FTIR Mg/Al-LDH

Berdasarkan Gambar 1 terlihat puncak serapan pada bilangan gelombang $447 \mathrm{~cm}^{-1}$ yang merupakan vibrasi ikatan $\mathrm{Mg}-\mathrm{O}-\mathrm{Al}$ pada struktur Mg/Al-LDH [9]. Serapan yang melebar pada bilangan gelombang di bawah $1000 \mathrm{~cm}^{-1}$ berhubungan dengan serapan $\mathrm{Mg}-\mathrm{OH}$ atau Al$\mathrm{OH}$ [10]. Pada bilangan gelombang $3459 \mathrm{~cm}^{-1}$ terdapat serapan kuat dan melebar yang menunjukkan vibrasi stretching $\mathrm{O}-\mathrm{H}$ dari permukaan $\mathrm{Mg} / \mathrm{Al}-\mathrm{LDH}$ dan molekul air yang ada di daerah antar lapis Mg/Al-LDH. Selain itu, molekul air yang terdapat di daerah antar lapis Mg/Al-LDH juga ditunjukkan oleh puncak serapan pada bilangan gelombang $1635 \mathrm{~cm}^{-1}$.

Adanya anion nitrat pada Mg/Al-LDH ditunjukkan oleh puncak serapan yang relatif kuat pada bilangan gelombang $1383 \mathrm{~cm}^{-1}$ yang merupakan vibrasi stretching $\mathrm{N}-\mathrm{O}$ dari anion $\mathrm{NO}_{3}{ }^{-}$Hal ini juga diperkuat dengan adanya puncak serapan pada bilangan gelombang 688 $\mathrm{cm}^{-1}$ yang menunjukkan vibrasi bending $\mathrm{N}=\mathrm{O}$.

Padatan Mg/Al-LDH juga dikarakterisasi dengan difraktometer XRD yang bertujuan untuk mengetahui karakteristik puncak-puncak utama. Dari Gambar 2 nampak muncul puncak difraksi (110) pada $2 \theta 60,54^{\circ}$ mengindikasikan bahwa lapisan Mg/Al-LDH telah terbentuk. Posisi puncak difraksi (110) dapat mengindikasikan nilai parameter kisi $a$, 
dimana parameter kisi Mg/Al-LDH yang dihasilkan dalam penelitian ini adalah $3.06 \AA$. Parameter kisi kristal $a$ dari Mg/Al-LDH hasil sintesis ini konsiten dengan yang dihasilkan oleh [11]. Parameter kisi a pada LDH menunjukkan jarak antara dua gugus hidroksida yang berdekatan pada sisi lapisan yang sama atau menunjukkan jarak antara ion logam yang paling berdekatan yang ada di lapisan LDH.

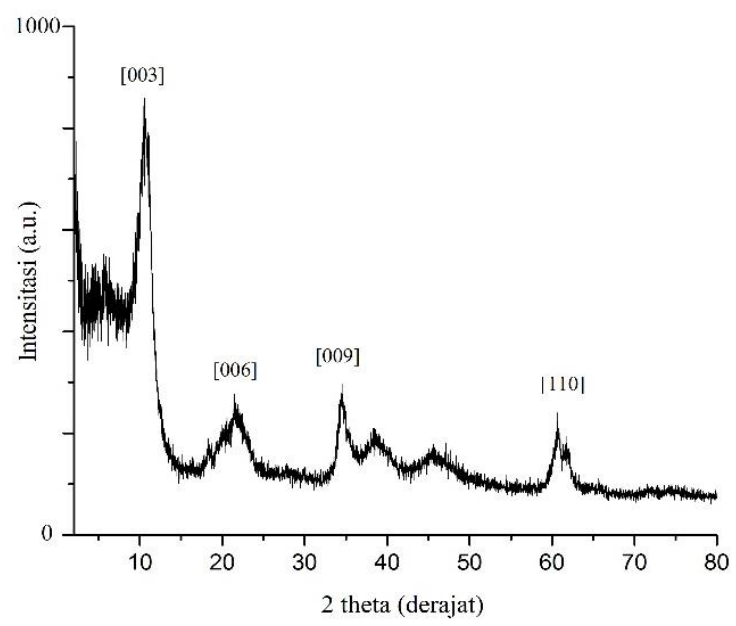

Gambar 2. Difraktogram XRD Mg/Al-LDH

Tiga puncak utama lain yang mempunyai intensitas relatif tinggi muncul pada sudut difrakasi $2 \theta 10,9 ; 21,22$; dan $34,48^{\circ}$ yang bersesuaian dengan harga $d$ sebesar 8,$11 ; 4,18$; dan 2,59 A. Data ini jika dibandingkan dengan harga data $d \mathrm{Mg} / \mathrm{Al}-\mathrm{LDH}$ hasil sintesis $\mathrm{Xu}$ dan Zeng (2001) terdapat kemiripan. Adanya anion nitrat pada antar lapis ini juga sesuai dengan yang dilaporkan oleh $\mathrm{Xu}$ dan Zeng (2001) bahwa Mg/Al-LDH yang mempunyai anion nitrat di daerah antar lapis memiliki $d_{003}$ sebesar 8,08-8,95 ̊ [11].

\section{Imobilisasi APHB pada Mg/Al-LDH Pengaruh keasaman}

Setelah sintesis $\mathrm{Mg} / \mathrm{Al}-\mathrm{LDH}$, tahapan berikutnya yaitu material $\mathrm{Mg} / \mathrm{Al}-\mathrm{LDH}$ yang dihasilkan diinteraksikan dengan larutan APHB. Untuk mempelajari pengaruh $\mathrm{pH}$ larutan terhadap imobilisasi, maka larutan APHB dibuat dalam beberapa $\mathrm{pH}$. $\mathrm{pH}$ merupakan parameter keasaman yang sangat penting dalam proses imobilisasi APHB pada permukaan Mg/Al-LDH. Hal ini dikarenakan perubahan keasaman larutan dapat mempengaruhi perubahan muatan struktur kimia adsorben maupun spesies adsorbat dalam larutan [12]. Mg/Al-LDH akan stabil pada $\mathrm{pH} \geq$
3, maka pada peneltian ini dibuat larutan APHB pada $\mathrm{pH} 3,5,7,9$, dan 11 [13].

Gambar 3 menunjukkan bahwa adsorpsi APHB pada material Mg/Al-LDH sangat dipengaruhi oleh $\mathrm{pH}$. Hasil penelitian menunjukkan bahwa adsorpsi APHB pada $\mathrm{Mg} / \mathrm{Al}-\mathrm{LDH}$ mengalami peningkatan dari $\mathrm{pH} 3$ sampai 7, di atas pH 7 yaitu sampai pH 11 adsorpsi APHB mengalami penurunan, sehingga dari penelitian ini $\mathrm{pH}$ optimum adsorpsi APHB pada $\mathrm{Mg} / \mathrm{Al}-\mathrm{LDH}$ terjadi pada $\mathrm{pH}$ 7. APHB memiliki $\mathrm{pK}_{\mathrm{a}} 1=4,57$ dan $\mathrm{pK}_{\mathrm{a}} 2=$ 9,46 sehingga seiring meningkatnya $\mathrm{pH}$ dari 4,5 sampai 9,5 maka spesies APHB yang bermuatan negatif akan dominan, dengan demikian jumlah APHB yang teradsorpsi di permukaan Mg/AlLDH pun juga semakin banyak.

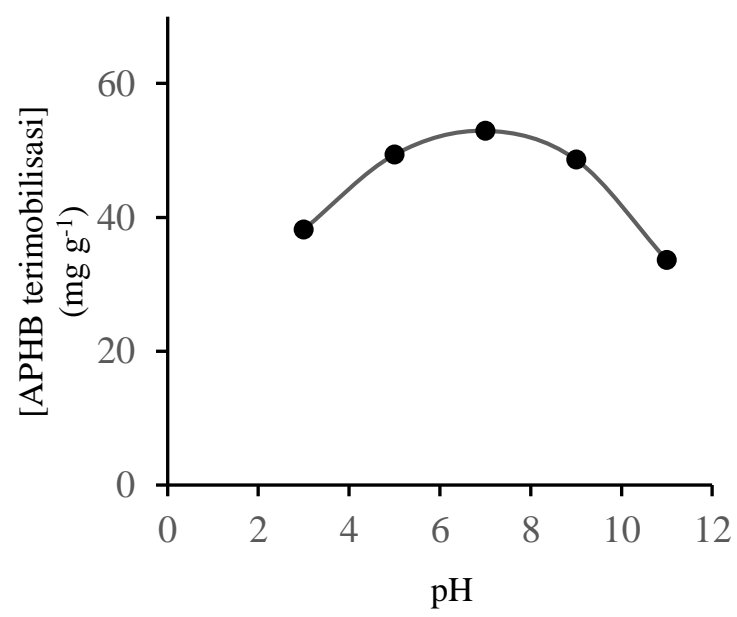

Gambar 3. Pengaruh $\mathrm{pH}$ terhadap imobilisasi asam para hidroksibenzoat pada Mg/Al-LDH

Dikaji dari sisi adsorben, $\mathrm{Mg} / \mathrm{Al}-\mathrm{LDH}$ memiliki nilai $\mathrm{pH}_{p z c}$ sebesar 12 [13, 14], yang menunjukkan bahwa di $\mathrm{pH} \leq 12 \mathrm{Mg} / \mathrm{Al}-\mathrm{LDH}$ mempunyai permukaan yang bermuatan positif, akan tetapi proses adsorpsi APHB pada penelitian ini menunjukkan penurunan ketika $\mathrm{pH}$ medium meningkat di atas $\mathrm{pH}$ 7. Hal ini dikarenakan semakin meningkatnya $\mathrm{pH}$ maka $\mathrm{Mg} / \mathrm{Al}-\mathrm{LDH}$ semakin berkurang sifat positifnya. Selain itu, penurunan jumlah anion APHB yang teradsorpsi dimungkinkan karena anion APHB mengalami kompetisi dengan adanya ion hidroksida yang berlebih di larutan yang mempunyai $\mathrm{pH}$ tinggi sehingga peluang anion APHB untuk berinteraksi denga situs aktif yang $\mathrm{Mg} / \mathrm{Al}-\mathrm{LDH}$ berkurang.

Berdasarkan pengamatan dalam proses imobilisasi APHB pada $\mathrm{Mg} / \mathrm{Al}-\mathrm{LDH}$ yang ditinjukkan pada Tabel 1 terlihat bahwa terjadi 
perubahan $\mathrm{pH}$ sebelum dan sesudah imobilisasi. Pada $\mathrm{pH} 3$ sampai dengan 7, terjadi kenaikan $\mathrm{pH}$ setelah proses adsorpsi APHB yang dikarenakan pada $\mathrm{pH}$ rendah sampai dengan $\mathrm{pH}$ 7 permukaan $\mathrm{Mg} / \mathrm{Al}-\mathrm{LDH}$ terprotonasi dimana ion $\mathrm{H}^{+}$akan lebih banyak terdapat di permukaan $\mathrm{Mg} / \mathrm{Al}-\mathrm{LDH}$ yang berakibat pada naiknya $\mathrm{pH}$ larutan.

Tabel 1. Hasil pengukuran $\mathrm{pH}$ sebelum dan sesudah imobilisasi APHB pada Mg/Al-LDH

\begin{tabular}{cc}
\hline $\begin{array}{c}\mathrm{pH} \text { larutan } \\
\text { sebelum imobilisasi }\end{array}$ & $\begin{array}{c}\mathrm{pH} \text { larutan } \\
\text { setelah imobilisasi }\end{array}$ \\
\hline 3 & 5,57 \\
5 & 6,02 \\
7 & 7,34 \\
9 & 8,11 \\
11 & 8,77 \\
\hline
\end{tabular}

LDH $\begin{gathered}\text { Terprotonasinya permukaan } \\ \text { sehingga }\end{gathered}$ bermuatan positif mengakibatkan banyak anion APHB yang teradsorpsi. Sebaliknya pada $\mathrm{pH}$ di atas 7, permukaan $\mathrm{Mg} / \mathrm{Al}-\mathrm{LDH}$ terdeprotonasi dimana ion $\mathrm{H}^{+}$lebih banyak menyukai untuk berada di dalam larutan sehingga permukaan $\mathrm{Mg} / \mathrm{Al}-\mathrm{LDH}$ menjadi bermuatan negatif. Permukaan $\mathrm{Mg} / \mathrm{Al}-$ LDH yang bermuatan negatif berakibat turunnya adsorpsi anion APHB dikarenakan adanya tolakan ionik antara permukaan $\mathrm{Mg} / \mathrm{Al}$ LDH dan anion APHB.

\section{Kapasitas imobilisasi APHB pada Mg/Al- LDH.}

Kapasitas adsorpsi APHB pada Mg/AlLDH ditentukan menggunakan model isoterm adsorpsi. Isoterm adsorpsi dilakukan untuk mempelajari imobilisasi APHB pada $10 \mathrm{mg}$ $\mathrm{Mg} / \mathrm{Al}-\mathrm{LDH}$ dengan melakukan variasi konsentrasi APHB pada kisaran 5-400 $\mathrm{mg} \mathrm{L}^{-1}$ pada $\mathrm{pH}$ 7. Data adsorpsi kemudian ditransformasikan ke variabel-variabel yang sesuai dengan persamaan model non linear isoterm untuk mengevaluasi hasil pencocokan (fitting) data adsorpsi terhadap model isoterm Langmuir dan Freundlich.

$\underline{\text { Tabel 2. Parameter model nonlinear isoterm adsorpsi Langmuir dan Freundlich }}$

\begin{tabular}{ccccc}
\hline Model isoterm & $R^{2}$ & $K$ & $n$ & $q_{\text {maks }}$ \\
\hline Langmuir & 0,9765 & $0,31 \mathrm{mg}^{-1}$ & - & $62,16 \mathrm{mg} \mathrm{g}^{-1}$ \\
Freundlich & 0,7383 & $21,48 \mathrm{mg} \mathrm{g}^{-1}$ & 5,08 & - \\
\hline
\end{tabular}

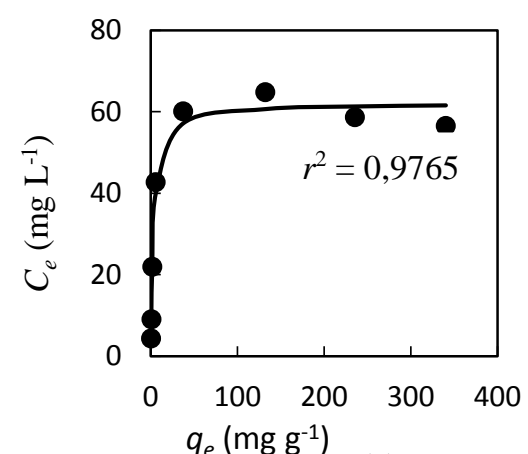

(a)

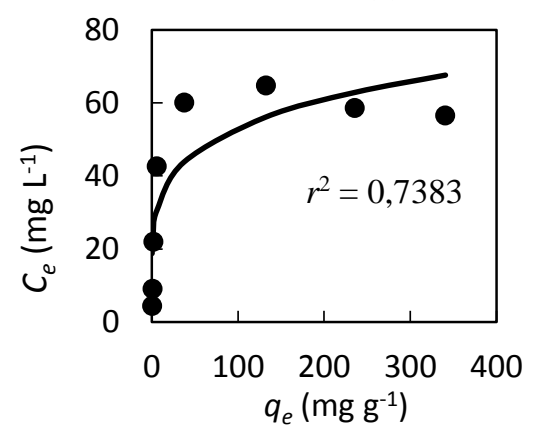

(b)
Gambar 4. Plot data adsorpsi APHB pada $\mathrm{Mg} / \mathrm{Al}-\mathrm{LDH}$ dengan model: (a) isoterm Langmuir dan (b) isoterm Freundlich

Tabel 2 dan Gambar 4 menunjukkan bahwa isoterm Langmuir lebih sesuai daripada isoterm Freundlich dengan data adsorpsi APHB pada $\mathrm{Mg} / \mathrm{Al}-\mathrm{LDH}$, dimana nilai $r^{2}$ dari isoterm Langmuir jauh lebih besar dibandingkan nilai $r^{2}$ dari isoterm Freundlich. Dari hasil pencocokan data adsorpsi APHB pada Mg/Al-LDH dengan model non linear tersebut menunjukkan bahwa terdapat kemiripan dan konsistensi hasil antara model isoterm linear dan nonlinear, dimana adsorpsi APHB pada $\mathrm{Mg} / \mathrm{Al}-\mathrm{LDH}$ mengikuti isoterm Langmuir. Hal ini memberikan informasi bahwa situs aktif pada permukaan $\mathrm{Mg} / \mathrm{Al}-\mathrm{LDH}$ adalah homogen dan tidak terdapat interaksi antar 
molekul APHB, sehingga adsorpsi APHB pada permukaan $\mathrm{Mg} / \mathrm{Al}-\mathrm{LDH}$ hanya membentuk satu lapisan. Berdasarkan model non linear isoterm Langmuir, diperoleh kapasitas $\mathrm{Mg} / \mathrm{Al}-\mathrm{LDH}$ untuk mengadsorpsi APHB adalah 62,16 $\mathrm{mg} \mathrm{g}^{-1}$, yang artinya per gram $\mathrm{Mg} / \mathrm{Al}-\mathrm{LDH}$ mengandung 62,16 $\mathrm{mg} \mathrm{g}^{-1}$ APHB, dengan nilai konstanta Langmuir $\left(K_{a}\right)$ sebesar 0,31 $\mathrm{L} \mathrm{mg}^{-1}$.

\section{Karakterisasi Mg/Al-LDH Terimobilisasi APHB}

Analisis spektroskopi FTIR material hibrida $\mathrm{Mg} / \mathrm{Al}-\mathrm{LDH}$ terimobilisasi APHB yang disintesis pada kondisi $\mathrm{pH}$ dan konsentrasi APHB optimum disajikan pada Gambar IV.11. Beberapa perbedaan terlihat pada spektra material $\mathrm{Mg} / \mathrm{Al}-\mathrm{LDH}$ sebelum dan sesudah diinteraksikan dengan APHB. Nampak bahwa terjadi perubahan pola spektra IR di bawah bilangan gelombang $1000 \mathrm{~cm}^{-1}$ yang berhubungan dengan ikatan logam-logam $\mathrm{Mg}$ atau $\mathrm{Al}$ dengan oksida (M-O) yang ada pada permukaan sejenis brucite $(\mathrm{Mg} / \mathrm{Al}-\mathrm{OH})$. Hal ini mengindikasikan bahwa telah terjadi adsorpsi pada permukaan sejenis brucite yang bermuatan positif (Heraldy dkk., 2011).

Pada Gambar 5 terlihat penurunan puncak serapan pada daerah bilangan gelombang $3447 \mathrm{~cm}^{-1}$ yang menunjukkan pengurangan pada gugus hidroksi pada permukaan $\mathrm{Mg} / \mathrm{Al}-\mathrm{LDH}$ dan dari molekul $\mathrm{H}_{2} \mathrm{O}$ yang terdapat pada daerah antar lapisnya. Hal ini mengindikasikan bahwa adsorpsi telah terjadi pada permukaan $\mathrm{Mg} / \mathrm{Al}-\mathrm{LDH}$ sehingga jumlah $-\mathrm{OH}$ berkurang. Pengurangan intensitas puncak serapan juga terjadi pada serapan overtone ion nitrat pada bilangan gelombang $1383 \mathrm{~cm}^{-1}$ yang diperkirakan adanya perubahan pada ion nitrat yang kemungkinan telah mengalami protonasi menjadi asam nitrat yang kemudian dapat larut dalam air [15].

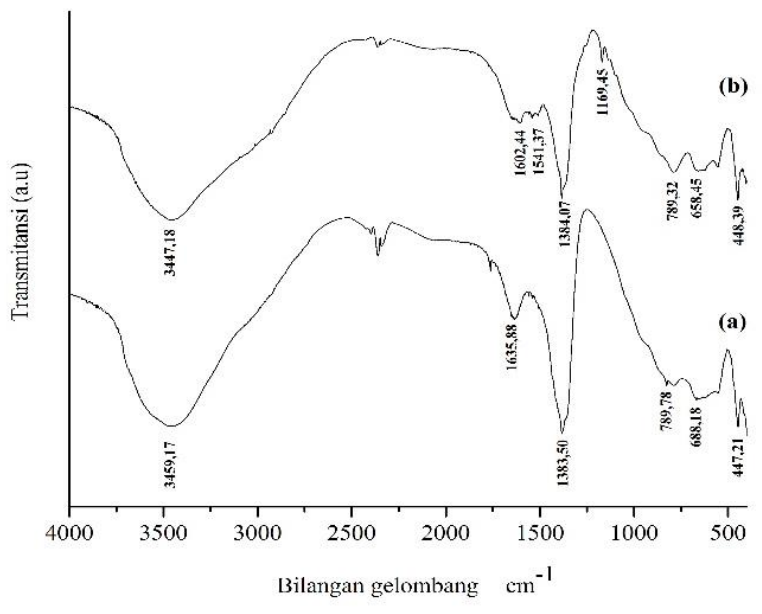

Gambar 5. Spektra FTIR: (a) Mg/Al-LDH (b) $\mathrm{Mg} / \mathrm{Al}-\mathrm{LDH}$ terimobilisasi APHB

Gambar 5 juga menunjukkan munculnya puncak serapan baru pada beberapa bilangan gelombang. Seperti puncak serapan pada bilangan gelombang 1541 dan $1602 \mathrm{~cm}^{-1}$ yang masing-masing merupakan serapan vibrasi stretching $\mathrm{C}=\mathrm{C}$ cincin aromatis dan vibrasi stretching asimetri R-COO- dari anion APHB. Pada bilangan gelombang $1169 \mathrm{~cm}^{-1}$ terekam puncak serapan baru. Puncak serapan pada bilangan gelombang 1169 diperkirakan merupakan vibrasi stretching $\mathrm{C}-\mathrm{O}$ dari gugus fenolat.

XRD $\begin{array}{ccr}\text { Karakterisasi } & \text { dengan } & \text { difraktometer } \\ \text { dimaksudkan untuk mengetahui }\end{array}$ perubahan puncak-puncak karakteristik pada $\mathrm{Mg} / \mathrm{Al}-\mathrm{LDH}$ sebelum dan sesudah adsorpsi APHB. Proses adsorpsi pada Mg/Al-LDH dapat terjadi melaui dua cara, yang pertama yaitu interaksi elektrostatik yang memanfaatkan muatan positif pada permukaan $\mathrm{Mg} / \mathrm{Al}-\mathrm{LDH}$ dengan muatan negatif yang ada pada adsorbat, yang kedua yaitu melalui pertukaran anion yang ada di daerah antar lapis. Dengan mengamati pergeseran basal spacing $d_{003}$ pada $\mathrm{Mg} / \mathrm{Al}-\mathrm{LDH}$ maka secara tidak langsung dapat memberikan informasi apakah proses adsorpsi terjadi melalui pertukaran anion antar lapis atau tidak. 


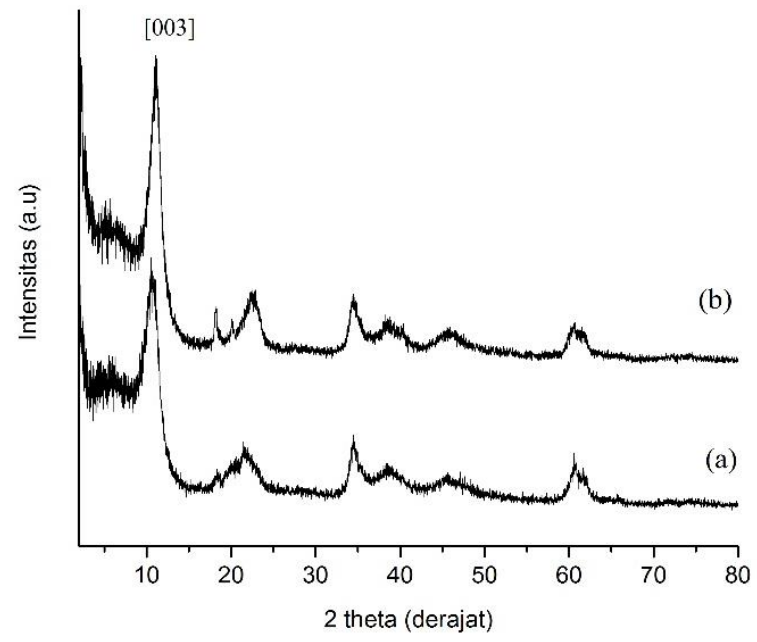

Gambar 6. Difraktogram XRD material: (a) $\mathrm{Mg} / \mathrm{Al}-\mathrm{LDH}$ dan (b) Mg/Al-LDH terimobilisasi APHB

Basal spacing $d_{003}$ pada $\mathrm{Mg} / \mathrm{Al}-\mathrm{LDH}$ menunjukkan jarak daerah antar lapis. Jarak antar lapis tersebut tergantung pada jenis anion yang mengisi, sehingga dapat dijadikan indikasi apabila nilai basal spacing $d_{003}$ mengalami perubahan yang signifikan, dimungkinkan telah terjadi pergantion anion (anion exchange) di daerah antar lapis. Apabila setelah proses adsorpsi nilai basal spacing $d_{003}$ dari $\mathrm{Mg} / \mathrm{Al}-$ LDH tidak berubah maka dimungkinkan adsorpsi APHB pada Mg/Al-LDH terjadi melalui interaksi elektrostatik yang memanfaatkan muatan positif pada permukaan $\mathrm{Mg} / \mathrm{Al}-\mathrm{LDH}$.

Difraktogram hasil analisis material $\mathrm{Mg} / \mathrm{Al}-\mathrm{LDH}$ setelah adsorpsi APHB dengan XRD memperlihatkan harga sudut difraksi yang relatif sama dengan difraktogram $\mathrm{Mg} / \mathrm{Al}-\mathrm{LDH}$ sebelum adsorpsi (Gambar 6). Hal ini menunjukkan bahwa tidak terjadi perubahan struktur pada $\mathrm{Mg} / \mathrm{Al}-\mathrm{LDH}$ pasca adsorpsi. Perbedaan yang terlihat yaitu terjadi penurunan basal spacing $d_{003}$ meskipun tidak terlalu signifikan yakni dari 8,11 menjadi 7,90. Berdasarkan data tersebut (Tabel 3) maka dapat dikatakan bahwa APHB hanya berada di permukaan $\mathrm{Mg} / \mathrm{Al}-\mathrm{LDH}$ dan tidak masuk ke daerah antar lapis. Penurunan basal spacing $d_{003}$ Mg/Al-LDH dimungkinkan karena APHB mempunyai sifat hidrofilik yang menjadikannya mampu berinteraksi dengan baik terhadap $\mathrm{H}_{2} \mathrm{O}$. Hal tersebut dapat menjadi gaya dorong (driving force) APHB untuk menarik molekul $\mathrm{H}_{2} \mathrm{O}$ yang ada di daerah antar lapis sehingga menurunkan nilai basal spacing $d_{003} \mathrm{Mg} / \mathrm{Al}-\mathrm{LDH}$.
Tabel 3. Data harga $d(\AA) /(2 \theta)$ karakteristik $\mathrm{Mg} / \mathrm{Al}-\mathrm{LDH}$ sebelum dan sesudah adsorpsi APHB

\begin{tabular}{lc}
\multicolumn{2}{c}{ APHB } \\
\hline Mg/Al-LDH & $d(\AA) /(2 \theta)$ (derajat) \\
\hline Sebelum & $8,11 / 10,90$ \\
adsorpsi & $4,18 / 21,22$ \\
& $2,59 / 34,48$ \\
& $1,53 / 60,54$ \\
\hline Setelah & $7,90 / 11,19$ \\
adsorpsi & $3,89 / 22,87$ \\
& $2,60 / 34,37$ \\
& $1,54 / 60,29$ \\
\hline
\end{tabular}

\section{KESIMPULAN}

Sintesis dan karakterisasi $\mathrm{Mg} / \mathrm{Al}-$ LDH terimobilisasi asam para hidroksibenzoat telah berhasil dilakukan. Berdasarkan pola difrasi sinar-X, struktur material tersebut tidak mengalami peningkatan daerah antar lapis yang menunjukkan bahwa asam para hidroksibenzoat terimobilisasi di permukaan $\mathrm{Mg}$ /Al-LDH. Hal ini juga didukung oleh hasil identifikasi melalui spektroskopi FTIR bahwa terdapat terdapat gugus-gugus fungsi spesifik asam para hidroksibenzoat di material hibrida tersebut.

\section{DAFTAR PUSTAKA}

1. Gu, Z., Atherteon, J.J. dan Xu, Z.P., "Hierarchical Layered Double Hydroxide Nanocomposite: Structure, Synthesis and Applications," Chem. Commun., vol 2, pp. 1-13, 2010.

2. Tong, Z., Shichi, T. dan Takagi, K., "Oxidation Catalyisis of Manganese(III) Porphyrin Intercalated in Layered Double Hydroxide Clays, Mater. Lett., vol 57, pp. 2258-2261, 2003.

3. Ma, Shulan, Lu Hang, Lijio M., Yurina S., Saiful M. I., Pengli W., Li-Dong Z., Shichao W., Gerban S., Xiaojing Y., Mercouri G. K., "Efficient Uranium Captured by Polysulfide/Layered Double 
Hydroxide Composites," J. Am. Chem. Soc., vol 137 (10), pp. 3670-3677, 2015

4. Feng, M. L., Debajit S., Xing-Hui Q., KeZhou D., Xiao-Ying H., Mercouri G. K., "Effiecient Removal and Recovery of Uranium by a Layered Organic-Inorganic Hybrid Thiostannate," J. Am. Chem. Soc., vol 138 (38), pp. 12578-12585, 2016.

5. Fitriani, D., Immobilisasi Asam Galat pada Mg/Al Hidrotalsit dan Aplikasinya untuk Removal $\mathrm{AuCl}_{4}^{-}$: Jurusan Kimia FMIPA UGM, 2013.

6. Maghfiroh, Pengaruh Posisi Gugus Hidroksi Senyawa Turunan Asam Benzoat terhadap Pembentukan Nanopartikel Perak dari $\mathrm{AgNO}_{3}$ : Jurusan Kimia FMIPA UGM, 2015.

7. Karoonian, F.S., Etesami, M. dan Mohamed, N., "Electrodepositionof Au on Reticulated Vitreous Carbon from Chloride Media by an Electrogenerative Process." Int. J. Electrochem. Sci., vol 7 (4), pp. 3059-3071, 2012.

8. Lin, Y.J., Li, D.Q., dan Duan, X., "Modulating Effect of $\mathrm{Mg}-\mathrm{Al}-\mathrm{CO}_{3}$ Layered Double Hydroxide on the Thermal stability of PVC Resin," Polym. Degrad. Stab., vol 88, pp. 286-293, 2015.

9. Kloprogge, J.T., Wharton, D., Hickey, L. dan Frost R, L., "Infared and Raman Study od Interlayer Anions $\mathrm{CO}_{3}{ }^{2-}, \mathrm{NO}_{3}^{-}, \mathrm{SO}_{4}{ }^{2-}$, and $\mathrm{ClO}_{4}^{-}$in $\mathrm{Mg} / \mathrm{Al}$ Hydrotalcite," $\mathrm{Am}$. Min, vol 87, pp. 623-629, 2002.

10. Hickey, L., Klopprogge, J.T, dan Frost, R.L., "The ffect of Various Hydrothermal Treatments on Magnesium-Aluminium Hydrotalcites," J. Mater. Sci., vol 35, pp. 4347-4353. 2000.

11. Xu, Z.P. dan Zeng, H.C., "Ionic Intercalations in Cristallite Growth of CoMgAl-Hydrotalcite-like Compounds," J. Chem. Mater., vol 13, pp. 4555-4563, 2001.

12. Stumm, W., dan Morgan, J. J., Aquatic Chemistry: Chemical Equilibria in Natural Water, 3rd ed.,: John Willey \& Sons., Inc., 1996.

13. Heraldy, E., Santosa, S.J. dan Wijaya, K., "Synthesis of $\mathrm{Mg} / \mathrm{Al}$ Hydrotalcite-like from Brine Water and Its Application for Methyl Orange Removal: A Preliminary Study," Makara Sains, vol 15 (1), pp. 915, 2011.
14. Martin, M.J.S., Villa, M.V., and Camazano, M.S., "GlyphosateHydrotalcite Interaction as Influenced by pH," Clays Clay Miner., vol 47, pp. 777783, 1999.

15. Rovita, E., Imobilisasi Asam Salisilat pada Mg/Al-Hydrotalcite dan Aplikasinya untuk Adsorpsi-Reduksi $\mathrm{AuCl}_{4}^{-}$: Universitas Gadjah Mada, 2013 